\title{
ARF1 wt Allele
}

National Cancer Institute

\section{Source}

National Cancer Institute. ARF1 wt Allele. NCI Thesaurus. Code C143143.

Human ARF1 wild-type allele is located in the vicinity of $1 \mathrm{q} 42.13$ and is approximately 17 $\mathrm{kb}$ in length. This allele, which encodes ADP-ribosylation factor 1 protein, plays a role in intracellular protein trafficking. 